\title{
Furcsa realizmus, spekulatív pedagógiai fordulat
}

\author{
Vályi Péter \\ Eszterházy Károly Egyetem Neveléstudományi Doktori Iskola \\ doktorandusza \\ valyipeti@gmail.com
}

Lysgaard, 7. A., Bengtsson, S., \& Laugesen, M. H.-L. (2019). Dark pedagogy: Education, horror and the anthropocene. https://doi.org/10.1007/978-3-030-19933-3

DOI : 10.37205/TEL-hun.2019.3-4.11

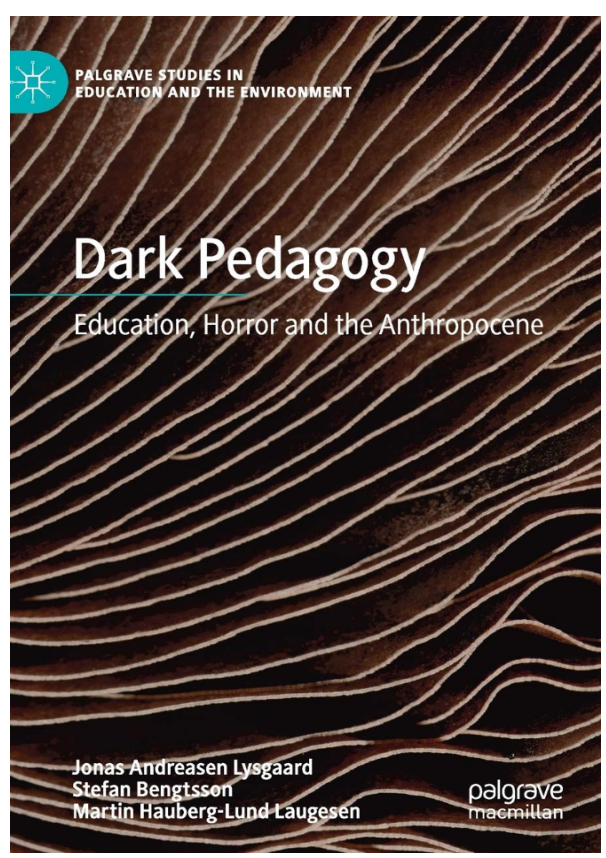

A recenzió a Dark Pedagogy, Education, Horror and the Anthropocene címü 2019-es kiadású oktatásfilozófiai tanulmánygyüjteményt ismerteti, mely az antropocén témájában zajló diskurzusban helyezhető el.

Kárász (2015) környezeti nevelésre vonatkozó történeti áttekintéséből kiderül, hogy a környezetpedagógia a maga eszközrendszerén belül mindig igyekezett többé-kevésbé időben reagálni a tágabb társadalmi és tudományos diskurzusok generálta nagy paradigmaváltásokra. Századunkban azonban kibontakozóban van egy olyan humán tudományos áramlat, amely a globális válsággal párhuzamosan alapvető jelentésválságról is beszél az antropocentrizmussal szemben gyakorolt kritikán keresztül. Ez a diskurzus megteremti annak a lehetőségét, hogy az eddig sziklaszilárdnak vélt fogalmak, mint például a fenntarthatóság, a természet, az ember, a cselekvőképesség, a pedagógia, a nevelés újratárgyalásra- újragondolásra kerülhessenek. A kötet szerzői ennek függvényében arra a kérdésre adnak választ, hogy a folyamatban lévő ökológiai, klimatológiai, környezeti válság miként befolyásolhatja a pedagógiáról való gondolkodást.

A recenzióban elsőként a mű, illetve a szerzők bemutatására térek ki, ezt követően a kötet fő fogalmainak, filozófiájának ismertetése következik. Az utolsó be- 
kezdésben a kötetben vázolt pedagógiai kérdések és jelenségek már tapasztalható és várható hatásainak bemutatására teszek kísérletet.

\section{A könyv tartalmi áttekintése}

A kötet elemzése során vizualitás irányából a tartalom felé haladva, megállapíthatjuk, hogy a borítója, továbbá a sötét pedagógia szimbóluma (Cthulu, Hórusz szeme) előrevetíti a tartalmat. A könyv borítójára, szimbólumára vonatkozott emailes megkeresésre a szerzők a következő választ adták: A borítón látható hullámzás végtelen, organikus, befejezetlen, alkalmas a sötét pedagógia furcsa valóságról alkotott koncepciójának kifejezésére. A tanulmánygyüjtemény angol nyelven, a Palgrave Macmillan kiadó gondozásában jelent meg Svájcban 2019-ben, egyéb fordításban nem olvasható. A kötet egy környezet- és fenntarthatóság pedagógiájával foglalkozó szaktudományos sorozat a Palgrave Studies in Education and the Environment keretein belül került kiadásra, amely a szakterület jövőbeli kérdéseire kíván alternatívákat szolgáltatni. A kiadvány hét egymásra épülő elméleti tanulmányt tartalmaz, amelyek közül az első, mint alapozó tanulmány Introduction: Living in Dark Times (Lysgaard - Laugesen - Bengtsson, 2019, 1-22. o.) deklarálja a kötet szerzőinek céljait, a pedagógiával szembeni kihívásokat, továbbá tisztázásra és definiálásra kerülnek a kötet meghatározó fogalmai. A további hat tanulmány két fejezetben elrendezve olvasható. Az első fejezet, The Horror of Education (Lysgaard és mtsai, 2019, 23-86. o.) egy-egy tanulmányt tartalmaz a három szerzőtől, amelyek külön-külön részletesen kitérnek a sötét pedagógia alapvetéseire és úgynevezett háromágú pszichológiai mezőjére (tagadás-őrülethalál). A második fejezet Towards to a Dark Pedagogy (Lysgaard és mtsai, 2019, 87-159. o.) az első fejezetben bemutatott alapvetések mentén a sötét pedagógia három lehetséges irányát, értelmezését mutatja be. A kötet tanulmányai szakirodalmi szintézisek, amelyek során a három szerző kortárs filozófiai, oktatásfilozófiai, természettudományos narratívákat egymásmellé helyezve hozza létre a sötét pedagógia sajátos nyelvezetét és annak tartalmi elemeit. A kötet nyelvezete a mash up építkezési módból kifolyólag meglehetősen bonyolult, az egyes területek közötti dinamikus mozgás mindvégig jellemezi a szövegeket. Lévén, hogy a tanulmányok által keretezett pedagógiai koncepció a kortárs filozófia speciális, spekulatív realista irányzataira támaszkodik, megköveteli ezen irányzatot képviselő gondolkodók műveinek, főbb elméleteinek mély és értő ismeretét. A tanulmányok bibliográfiája alapján a felhasznált filozófiai források rövid kivonata a következő: 
Object Oriented Ontology- A new theory of everything (Harman, 2016), Weird Realism: Lovecraft and Philosophy (Harman, 2012), After finitude, An Essay on the Necessity of Contingency (Mellisaux, 2006), The Ecological Thought (Morton, 2010), Hyperobjects, Philosophy and Ecology after the End of the World (Morton, 2013), In the Dust of this Planet (Thacker, 2011), After Life (Thacker, 2010), Nihil Unbound: Enleightenment and Extinction (Brassier, 2007).

A terjedelem ellenére nagyívű teoretikus munkát reprezentáló kötetről van szó, amely nem fogalmaz meg konkrét javaslatokat a gyakorlatra vonatkozóan és nem tartalmaz empirikus kutatási eredményeket.

\section{Szerzők}

A svéd és dán származású szerzők a pedagógiai kutatás területén dolgoznak, ezen belül is a környezeti és fenntarthatóságra nevelés területén belül folytattak kutatásokat az elmúlt években. Jonas Andreasen Lysgaard a Danish School of Education kutatója, szakterülete a klímaoktatás és az oktatásfilozófia. Stefan Bengtsson a svéd Upsala Universitet munkatársa, kutatási területe a didaktika és a fenntarthatóság pedagógiája. Martin Hauberg Lund-Laugesen svéd kutató, szakterülete a kultúratudományok. A Dark Pedagogy 2019-es kiadását megelőzően a szerzők több tanulmányt is publikáltak a pedagógia és a spekulatív, illetve a tárgyorientált filozófia kapcsolatainak témakörében.

\section{A könyv központi fogalmai}

\section{Antropocén}

Az antropocén eredetileg egy természettudományos, azon belül is geológia területére alkotott terminus, amely a 2000-es években vált közismertté Paul J. Crutzen légkörkémikusnak köszönhetően (Horváth, Lovász és Nemes, 2019). Az antropocén, magyar fordításban 'az ember kora', vagy 'új emberi kor' eredetileg egy új, a holocént váltó földrétegtani, földtörténeti kifejezés, amelynek kezdete jelen állás szerint 1945-1950-re tehető (Crutzen, 2019). A terminus bevezetését az emberiség geológiai léptékű fizikai tényezővé válásának ténye indukálta. Ennek eredménye egy közel 200 éve tartó globális környezetformálás lett, amely egy antropogén réteget hozott létre a talaj felső rétegében, illetve a bolygó légkörében, amelyek a becslések szerint az emberiség esetleges eltűnését követően emlékműként maradhatnak fent (Crutzen, 2019). Az antropocén mára interdiszciplináris fogalommá 
nőtte ki magát, a tudományok széles körét szólítja fel az arról szóló diskurzusba való becsatlakozásra, ezért a kifejezés alatt egyaránt értendő klimatológiai, ökológiai, környezeti, humanitárius és etikai válság.

\section{Spekulatív Realizmus}

A Spekulatív Realizmus (továbbiakban SR) annak a vitának a filozófiai reflexiója, amely az antropocént az antropocentrikus világkép, a humanizmus globális válságtüneteként aposztrofálja. Az SR az emberközpontú világkép kritikai ellenpárjaként a humán szubjektum megkülönböztetett, kiváltságos helyzetének megtagadására épül, ezzel azt mondva, hogy az emberi gondolkodás nem biztosít teljes hozzáférést a valósághoz (Harman, 2016). Harman értelmezésében a valóságot objektumok népesítik be (Bryant, 2011; Harman, 2016) A létezés ezen új értelmezése szakít a szubjektum-objektum ontológiai szakadékaival, és benne minden létező, így maga az ember is egy közös ontológiai síkra kerül (Bryant, 2011; Harman, 2016). A tárgyak a maguk totalitásában egyediek és nem redukálhatók (undermining) és nem is általánosíthatók (overmining), ezért a megismerés a szenzuális és a valós tárgy egyes aspektusainak kreatív vizsgálatain keresztül lehetséges (Harman, 2016). A valóság éppen ezért furcsa, idegen (unheimlich, idézi Fredudot Harman: Harman, 2012). Timothy Morton Hipertárgy-elmélete kiegészíti Harman objektum orientált ontológiáját, és azt mondja, hogy vannak bizonyos nagy kiterjedésű tárgyak, hipertárgyak (globális felmelegedés, radioaktív sugárzás, kapitalizmus), amelyek magasan az emberi képzelőerő, a tér-idő felfogás, illetve a kogníció és a percepció felett helyezkednek el, amelyek láthatatlanok, non-lokálisak, időben és térben hullámzók (Morton, 2013). A valóságot a felsejlő objektumok világán keresztül leíró, ezáltal kissé miszticizmusba hajló világnarratívával ellentétben a spekulatív materializmus esszencialista keretezése a valóságnak. A spekulatív materializmus a külvilágot (great outdoors) a matematika nyelvén tartja leírhatónak, amely globális rendszert alkot, így a bolygók rendszerét képes összehangolni a pohárban körkörös mozgást végző jégkockák pályájával (Mellisaux, 2006). A spekulatív pesszimizmus vagy kozmikus pesszimizmus a világegyetem, így az összes ismert-ismeretlen anyag megszünésének elkerülhetetlenségéből indul ki. Az értelem vagy jelentés elkerülhetetlen megszunnése a nihilizmust mint egyetlen adekvát viszonyulási módot, illetve filozófiai magatartásformánt implikálja (Brassier, 2007, Thacker, 2010, 2011). 


\section{Sötét pedagógia}

A pedagógia kifejezés előtt álló szokatlan, baljóslatú jelző a „sötét” tisztázása különösen fontos, tekintettel a hangulatában hasonlatos fekete pedagógiának (Schwarze Pedagogik) „gyermekre, mint alattvalóra tekintő" értelmezésére. Miként ezt Szekszárdi Júlia is összefoglalja a fekete pedagógia bevésődések formájában, defektusokat teremt, amelyek egy életen át megmaradnak a tanulókban, és későbbi felnőtt életük során akár renitens viselkedés, „revans” formájában is visszacsatolhatnak (Szekszárdi, 2007). A sötét pedagógia előtt álló „sötét” jelző többrétű olvasatot tesz lehetővé, ezért nem árt a félreértések elkerülése végett párat megnevezni ezek közül. A szerzők egyrészt, ezzel tisztelegnek a „filozófus próféta” Timothy Morton katalizátornak tekinthető Dark Ecology, azaz Sötét Ökológia elmélete előtt, amely a jelenségek-jelentések válságáról beszél (Morton, 2007, 2016). Röviden összegezve felszabadulás a felvilágosult fogalmak hegemón elnyomása alól, amely egyben lehetőség a bizonytalanba való kilépésre, és új, működő fogalmak kitalálására. Másrészt a „sötét” jelen esetben egy érzelmi rezonancia, amelyet a szerzők magukénak vallanak az antropocén negatívumaival szemben (Lysgaard és mtsai, 2019). Harmadrészt ez utalás az ontológiai bizonytalanságra, amely az árnyékzónában vészjóslóan cirkuláló objektumok okozta kényelmetlen érzetnek következtében alakul ki (Lysgaard és mtsai, 2019).

A sötét pedagógia az ún. Antropocén-paradoxonra épül, amelyet Laugusen fogalmaz meg. Az antropocén az emberközpontúság globális válságtünete, azonban ironikus módon az emberiség és az antropocén által felkorbácsolt ismert és még ismeretlen planetáris erők (globális felmelegedés, tengerszintemelkedés, egyéb időjárási, geológiai anomáliák) lehetnek azok az „ellenséges”-negatív tényezők, amelyek az eddig ismert civilizált világ vagy akár az emberiség, így antropocén eltörlésével fenyegetnek (Laugusen, 2019). Lysgaard az SR gondolkodóinak érvelését követve azt mondja, hogy az antropocén eddig példátlan kihívásokkal állítja szembe az emberiséget, és felszínre sodorja a valóság/világ nem emberi tényezőit, ezért a pedagógia legfőbb dolga csak abban ölthet testet elsődlegesen, hogy megtalálja a módot, amelyben elbeszélhetővé válik ezen új földtörténeti korszak a tanulók, a fiatalok számára (Lysgaard, 2019). Ezért is nagyon fontos tisztázni, hogy a sötét pedagógia nem az oktatás-nevelés tartalmára tesz javaslatot, hanem a tanulás, tanítás, tantárgy, tanuló fogalmainak, egymással alkotott interakcióinak spekulatív leírására tesz kísérletet. A tanuló és a tananyag, pontosabban a tanuló és a tananyag által közvetített valóság találkozásának leírására az egyik legalkal- 
masabb eszköz H. P. Lovecraft misztikus horror irodalmának szenvedő emberi szubjektumainak példája (Lysgaard és mtsai, 2019). Lovecraft realizmusa furcsa, idegen, az ismert és barátságos, családias világ képét ismeretlen, barátságtalan kép váltja fel, amelyet az emberi érzékszerveket összezavaró, magasan azok felett, vagy mélyen azok alatt rejtőző sötét entitások népesítenek be. Lovecraft alanyai kiszolgáltatottak, alávetettek ezeknek a monumentális entitásoknak, amelyek a gondolkodás és nyelv általi leírhatatlanságuknak köszönhetően a reakciók hármas egységébe rendezhető sorozatát váltják ki. A tagadás/megtagadás-őrület-halál hármasa írja le Lovecraft alakjainak pszichikai átváltozását. A sötét pedagógia három szerzője, erre a három mezőre épülve írja le a tanuló és a tananyag találkozásának lehetséges, spekulatív magyarázatát. Lysgaard a tagadás alatt egyrészt a tagadás egyéni vagy társadalmi funkcióját érti, amelynek során az egyén vagy egyének alkotta közösségek tudatosan ignorálnak egy tényt, mert az nem fér bele a valóságról alkotott prekoncepciójukba. Azonban, miként ezt felveti, a tagadás nemcsak egyéni-közösségi döntés lehet, a spekulativitás szemszögéből a valóság maga is megtagadhatja a hozzáférést a maga totalitásához, ezért annak tudatos számbavétele elkerülhetetlen (Lysgaard és mtsai, 2019). Laugesen az így kialakuló hozzáférhető/hozzáférhetetlen tartalmak okozta bizonytalan helyzetből való kilépés kapcsán beszél őrületről/abnormalitásról. A helyzet, amelyben ugyanis a már ismert jelölők alkalmatlanok egy hozzávetőlegesen ismert jelenség leírására, potenciális lehetőséget teremt az új, saját jelentések kreatív gyártására (Lund-Laugesen, 2019). Bengtsson a nehezen megismerhető tárggyal lefolytatott kreatív diskurzusban, majd az önálló jelentésgyártás által való „találkozás” aktusában a szépséggel való szembesülés aktusát asszociálja, amely minden egyes alkalommal az autonóm én-reprezentáció egy darabjának feloldódásához vezet (Bengtsson, 2019).

Harman és Lovecarft nyomán a sötét pedagógia számára a tanulás nem önazonos folyamat, egyrészt a tanulás folyamata korántsem azonos a tanulás céljával, másrészt mint társadalmi reprodukciós kísérlet mindig sikertelen, köszönhetően a kódolt interferenciáknak. Tovább haladva ezen analógián a tananyag sem korrelál a tananyag tartalmával, a szöveg mint jelölő csak részlegesen fedi le annak tárgyát, vagy egyáltalán nem áll kapcsolatban azzal. A tanulás nem redukálható ismeretek átadására, továbbá nem is általánosítható egy magasabb rendủ társadalmi elvárás szintjére (Lysgaard és mtsai, 2019). A tanulás a spekulatív filozófia, így a sötét pedagógia olvasatában felfedezés, amelyben tanuló és tanár közösen vesz 
részt, amely folyamat során a pedagógus mentor, facilitátor, aki egyaránt partner a tananyaggal való „találkozás” pillanatában, másrészt partner a közvetített tartalommal való konfrontálódás pillanatában. Azok a bizonyos kulcskompetenciák, amelyek gyakran visszaköszönnek a XXI. század szakmai vitáiban, mint például a kritikusságra, kreativitásra, önállóságra nevelés a sötét pedagógia olvasatában eleve jelen vannak a tanulás-tanítás folyamatában, a kutatók, a pedagógusok dolga éppen ezért ennek a ténynek a realizálása és nem kritikai praxisok kidolgozása. A sötét pedagógia a konstruktivista tanulás spekulatív eszközökkel kiegészített formáját vázolja fel, amelynek a központi problémája a jelentés-vesztés, jelentésgyártás az antropocén furcsa valóságában.

\section{A sötétség expanziója, spekulatív pedagógiai kutatások}

Azt, hogy a kötet nem közömbös a pedagógia számára, megerősíti az a tény, hogy az EERA (European Educational Research Association) által szervezett 20. ECER (European Conference on Educational Research) konferencia egyik hálózatának központi témája a sötét pedagógia. A hálózat felhívása szerint a konferenciára olyan anyagokat vártak, amelyek a pedagógia és a spekulatív realizmus, illetve az objektum orientált ontológia további kapcsolódási lehetőségeit kutatják, kiszélesítve ezzel a sötét pedagógia tárgykörét. A sötét pedagógiával foglalkozó szakemberek 2020-ban létrehozták a Dark Pedagogy Society-t, amely a jövőben a kutatások intézményesített formáját vetíti előre. Bár a kötet mindössze pár alkalommal tesz erről említést, a sötét pedagógia a környezet és a fenntarthatóság pedagógiáján belül zajló szakmai vita szerves részét kívánja képezni a jövőben. A második fejezet három tanulmánya, azok közül is Lund-Laugesen Dark pedagogy in the Anthropocene című tanulmánya, több alkalommal említést tesz a „sötét pedagógia oktatójáról”, illetve annak szerepéről, tanulás-tanítás folyamatában betöltendő funkciójáról. A kötet ebből adódóan a pedagógusképzés egy új tendenciáját is kilátásba helyezheti a jövőben (Lysgaard és mtsai, 2019, 103-143. o.). Bengtsson „nevelési gondolat” elmélete (Educational Thought) a tantárgyak sajátos ökológiájának koncepcióját vázolja fel, amely akár a nemzeti alaptantervek, az intézményi tantervek és a tanári tanmenetek újragondolását is elősegítheti (Lysgaard és mtsai, 2019, 144-159. o.).

A környezeti pedagógián belül zajló diskurzusok vonatkozásában a sötét pedagógia, illetve az SR egyaránt izgalmas kérdéseket vet fel. Az antropocén mint új földtörténeti korszak számos oktatásban-nevelésben magabiztosan használt össze- 
függés, fogalom felülvizsgálatát követeli meg vagy teszi lehetővé. Korántsem zárható ki egy olyan ciklus kezdete, amely a természet, a környezet, a fenntarthatóság és a szolidaritás fogalmait a pedagógián belül az antropocén vagy a sötét pedagógia aspektusából közelíti meg.

\section{Irodalom}

Brassier, R. (2007): Nihil Unbound: Enlightenment and Extinction. Palgrave Macmillan, London.

Crutzen P. (2019): Das Anthropozen. Oekom Verlag, Germany.

Harman, G. (2012): Weird Realism: Lovecraft and Philosophy. Zero Books, Winchester.

Harman, G. (2016): Object Oriented Ontology-A New Theory of Everithing. Pelican Books, UK.

Horváth M. - Lovász Á. - Nemes Z. M. (2019): A poszthumanizmus változatai. PRAE Kiadó, Budapest.

Kárász I. (2015): A környezeti nevelés története, céljai és eszközei. Környezeti nevelés és tudatformálás. Tanulmányok az Eszterházy Károly Főiskola mühelyeiből. Líceum Kiadó, Eger. 37-53.

Lysgaard J. A. - Laugesen L. M-H. - Bengtsson S. (2019): Dark Pedagogy, Education, Horror and the Anthropocene. Palgrave Macmillan, London.

Mellisaux, Q. (2006): After Finitude, Essays on Necessity of Contingency. Continuum, London.

Morton T. (2007): Ecology without Nature, Rethinking Environmental Aesthetics. Harvard University Press, Cambridge, London.

Morton, T. (2010): The Ecological Thought. Cambridge University Press, Cambridge, MA.

Morton, T. (2013): Hyperobjects, Philosophy and Ecology After the End of the World. Minnesota University Press, Minneapolis.

Morton T. (2016): Dark Ecology, Logic of Future Coexistense. Columbia University Press, New York.

Szekszárdi J. (2007): A fekete pedagógia jelenségvilága. Új Pedagógiai Szemle, 57. évf. 5. sz. 117-121.

Thacker, E. (2011): In the Dust of this Planet. Zero Books, Winchester.

Thacker, E. (2010): After Life. University of Chicago Press, Chicago. 